earlier operations, to have accounted for permanent restriction of absorption cf aqueous from the sub-conjunctival wounds.

It would be interesting to hear whether in other cases of this kind, unusual or prolonged post-operative reaction has been noticeable.

There was no trouble of any kind after the final iris-inclusion operation, and the posterior synechiae were not noticed at all at the operation. They were evidently very fine, and broke down at once. The prolapsed iris has become fibrosed, but the elevation is much more sharply defined and higher than usual, owing to restricted lateral diffusion of aqueous.

\title{
A CASE OF RING SARCOMA OF THE IRIS
}

BY

\section{DOROTHY R. ADAMS}

LONDON

History.-The patient, A. B., a mason's labourer, aged 44 years, was first seen on February 2, 1930, at the Central London Ophthalmic Hospital. He gave a history of a sudden attack of pain and inflammation in the left eye which began three weeks previously. The inflammation had subsided to some extent as the result of treatment, but the eye was still painful. Vision in that eye had been decreasing gradually for the past nine months, and was now lost almost entirely. There had been no previous attacks of inflammation.

Ciinical examination.-The left eye had bare perception of light. It was much inflamed and showed both ciliary and conjunctival injection. The tension was +2 , and the cornea was hazy and oedematous. The anterior chamber was deep, while the pupil was dilated and eccentric, being drawn downwards and outwards towards 5 o'clock. The iris was grey, and its normal pattern was somewhat obscured. In addition there was a striking irregular dark brown pigmentation forming two bands at 11 o'clock and extending round the iris to a larger patch at 5 o'clock. (When the pigmentation was remarked upon, the patient said that he had noticed the development of a brown spot on the nasal side of the iris during the last 12 months). With the loupe, a deposit of fine pigment could be seen on the posterior surface of the cornea. The fundus was barely visible, but the disc appeared cupped. The right eye was normal in all respects, with a full field and vision $6 / 6$. The iris was grey and had no extraneous deposits of pigment. A ring sarcoma of the uveal tract was diagnosed and the left eye was excised on February 25, 1930.

Macroscopic appearance.-On vertical section of the eyeball, a fine ring of dark pigment could be seen surrounding the anterior chamber in the region of the angle and coming forward on to the 


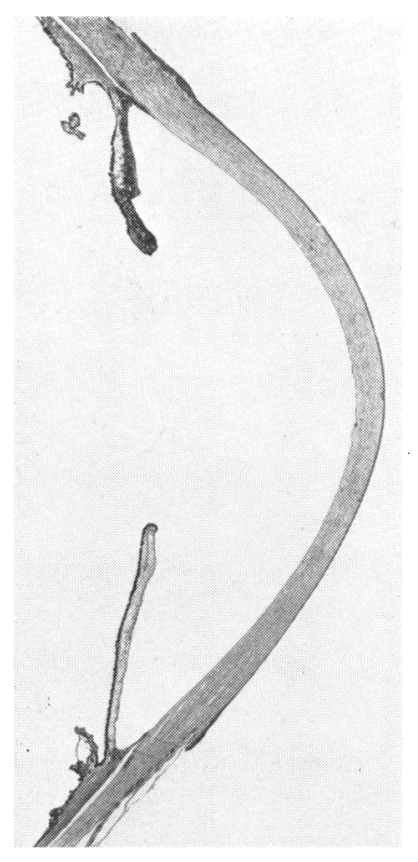

FIG. 1.

General view of growth showing invasion of angle on both sides. $(X 12)$. Celloidin section.

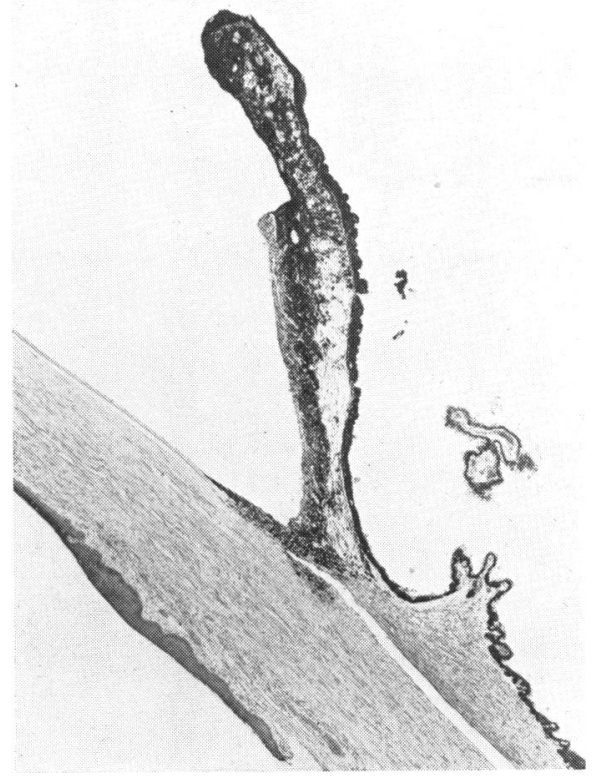

FIG. 2.

Showing extent of growth. $(\times 42)$. Celloidin section. 


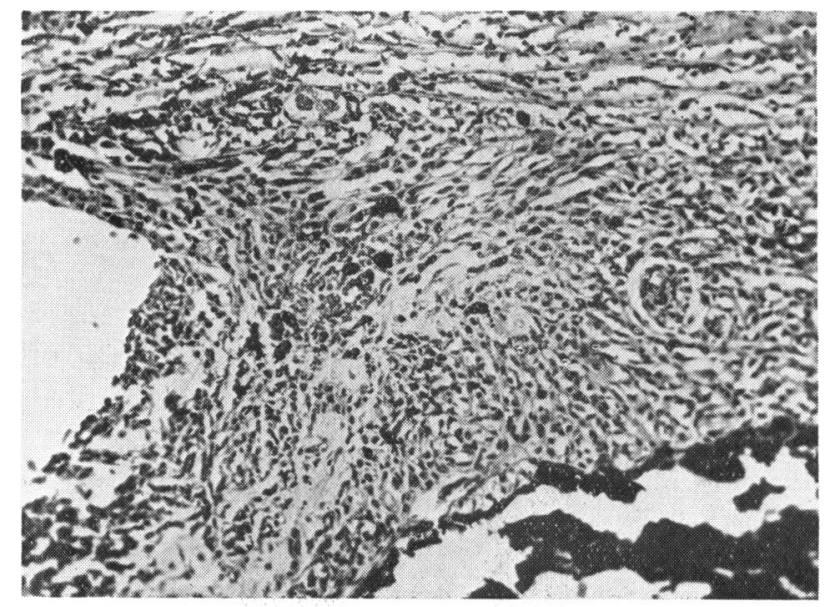

FIG. 3.

High power view showing distribution and cellular structure of growth $(X 250)$. The anterior chamber is on the left side. Unbleached paraffin section stained haematoxylin and van Gieson.

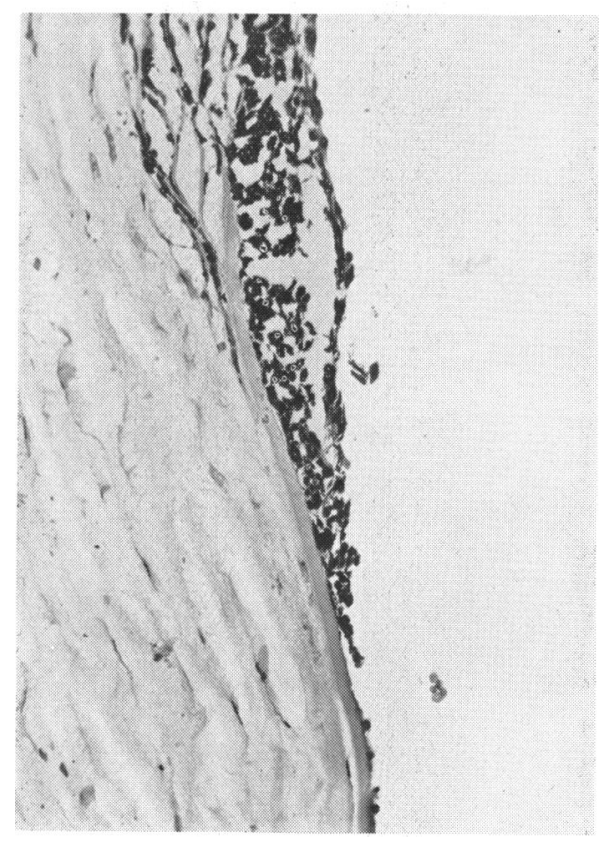

Extension of growth on both sides of Descemet's membrane. On the right the cells are continuous with the posterior endothelium. ( $\times 330)$ 
lower part of the cornea. The iris was thickened more especially in the region of its greatest eccentricity. The disc was cupped and the retinal vessels were engorged.

Microscopic appearance.-Both paraffin and celloidin sections were prepared, some being bleached.

On low power examination (see Fig. 1), a diffuse pigmented growth could be seen in the region of the filtration angle, invading the iris, 'the neighbouring sclera and the anterior part of the ciliary body. In every section which was examined there was involvement of the angle on both sides, thus indicating that the growth had a ring distribution. In agreement with the clinical appearance, the growth in certain places formed a flat mass replacing the anterior layers of the iris.

Under the high power, the growth was seen to consist chiefly of small spindle cells which could be seen particularly well on its free surface running parallel to the plane of the iris. (See Fig. 2). The cells were continued as a thin layer round the angle on to the back of the cornea where they were continuous with the posterior endothelium. Descemet's membrane was intact (see Fig. 4), but there was a slight invasion of the periphery of the cornea anterior to it. Outside the iris the growth was less compact, and in the filtration angle the cells formed small whorls and were separated by round spaces. (See Fig. 3). Schlemm's canal and the neighbouring vessels were surrounded by cells but were not actually invaded by them. The growth extended in a diffuse manner as far as the root of the ciliary processes.

The pigment was in excess of the actual growth, and formed large extracellular deposits while fine intracellular deposits could also be seen. The nuclei of the spindle cells were large in comparison with the size of cells. No mitotic figures were seen.

The growth seems to belong to the comparatively rare type of " ring " sarcoma of the iris, cases of which have been described by Solomon (1882), Meyerhof (1902), Parsons (1903), Alt (1911), Levan (1915), Pindikowski (1915), Li (1923), and Mayou (1930). Its special interest lies in the fact that it gave rise to symptoms of glaucoma, at such an early stage in its pathological development. In comparison, the growth had formed a definite tumour in each of the cases described previously.

\section{REFERENCES}

Alt.-Amer. Jl. of Ophthal., Vol. XXVIII, No. 6, June, 1911.

Levan.-Klin. Monatsbl. f. Augenheilk., p. 493, Oct.-Nov., 1915.

Li, T. M.-Amer. Jl. of Ophthal., Vol. LIII, p. 162, 1923.

Mayou.-Brit. Jl. of Ophthal., Vol. XIV, No. 4, p. 152, 1930.

Meyerhof.-Klin. Monatsbl. f. Augenheilk., Vol XL, i, p. 465, 1902.

Parsons.-A rch. f. Ophthal., Vol. LV, p. 350, 1903.

Pindikowski.-Klin. Monatsbl. f. Augenheilk., Vol. LIII, p 516, 1915.

Solomon.-Trans. Ophthal. Soc. U.K., Vol. II, p. 257, 1882. 